\title{
REMARKS ON POTAMOGETON HYBRIDS BASED ON CHARACTERS OF $P . \times$ SALICIFOLIUS WOLFG. FROM A NEW LOCALITY IN POLAND
}

\author{
JOANNA ZALEWSKA-GAŁOSZ \\ Department of Plant Taxonomy and Phytogeography \\ Institute of Botany, Jagiellonian University \\ Kopernika 31, 31-501 Cracow, Poland \\ e-mail: zalewska@ib.uj.edu.pl
}

(Received: February 12, 2003. Accepted: July 7, 2003)

\begin{abstract}
Information on Potamogeton hybrids, their identification, taxonomy, ecology and distribution has not been sufficiently recognised yet. Based on characters of $P . \times$ salicifolius $(=P$. perfoliatus $\times P$. lucens $)$ from a new locality in Poland - the Gatno lake (the Kaszuby Lakeland in NW Poland) - general comments on Potamogeton hybrids identification are introduced. The description of $P . \times$ salicifolius morphology from the Gatno lake are presented. Analysis of quantitative morphological characters of these specimens provided new information on variability of this taxon. The distribution map of $P . \times$ salicifolius in Poland, the original draft of $P . \times$ salicifolius based on specimens from the Gatno lake and the table with comparison of $P . \times$ salicifolius and the characters of parental species are also provided.
\end{abstract}

KEY WORDS: Potamogeton hybrids, variability, distribution, Potamogeton $\times$ salicifolius Wolfg.

\section{INTRODUCTION}

Potamogeton hybrids are taxonomically important because once established they could persist for many years spreading vegetatively (Preston 1995). Hybridisation in the genus Potamogeton has not been sufficiently recognised in Poland yet. Each new locality of Potamogeton hybrids provides information on frequency of occurrence and the distribution of these taxa. During a detailed, repeated study of hybrid population the habitat, hybrid fitness, biology and accompanying species can be assessed. This is invaluable information for recognising not only the number of Potamogeton hybrids occurring in Poland, but also for finding out whether these taxa are important components of the local floras.

Despite the fact that hybridisation in the genus Potamogeton is accidental, some species can hybridise more often than the others, for example $P . \times$ angustifolius J. Presl which is commonly distributed, whereas $P . \times$ nericius Hagstr. is very rare. The analysis of hybrid distribution pattern will only be possible if general distribution maps are prepared for these taxa.

During the field study in the Kaszuby Lakeland (Pojezierze Kaszubskie) in July 2002 a new locality of Potamogeton $\times$ salicifolius Wolfg. - the hybrid between $P$. perfoliatus and P. lucens - was recognised. The parental taxa distributions in Poland are presented in the „Distribution
Atlas of vascular plants in Poland" (Zajacc A., Zając M. 2001). This is the fifth locality of this rare Potamogeton hybrid in Poland (Fig. 1). The remaining four localities were revealed in the course of the revision of Potamogeton specimens collected in Polish Herbaria (approximately 5000 herbarium sheets, Zalewska-Gałosz unpublished). This taxon has not been identified in Poland before this revision (Lilienfeldówna 1919; Szafer et al. 1953; Mirek et al. 1995). During the revision also other rare Potamogeton hybrids were discovered (Zalewska-Gałosz 2002).

The aim of this paper is firstly to attract the florists' attention to Potamogeton hybrids problem and secondly to give new information on morphological variation of $P . \times$ salicifolius Wolfg.

\section{RECOGNITION}

The recognition of Potamogeton hybrids based on comparative morphology solely is only possible when hybridisation takes place between the broad-leaved species of $\mathrm{PO}_{O}$ tamogeton. In order to confirm the hybrid origin of the linear-leaved Potamogeton taxa isozymes study or DNA investigation should be conducted (Hollingsworth et al. 1995a, 1995b; Fant et al. 2001).

Potamogeton taxa could show extreme range of variation (Wiegleb 1988; Kaplan 2002) and are regarded as difficult 


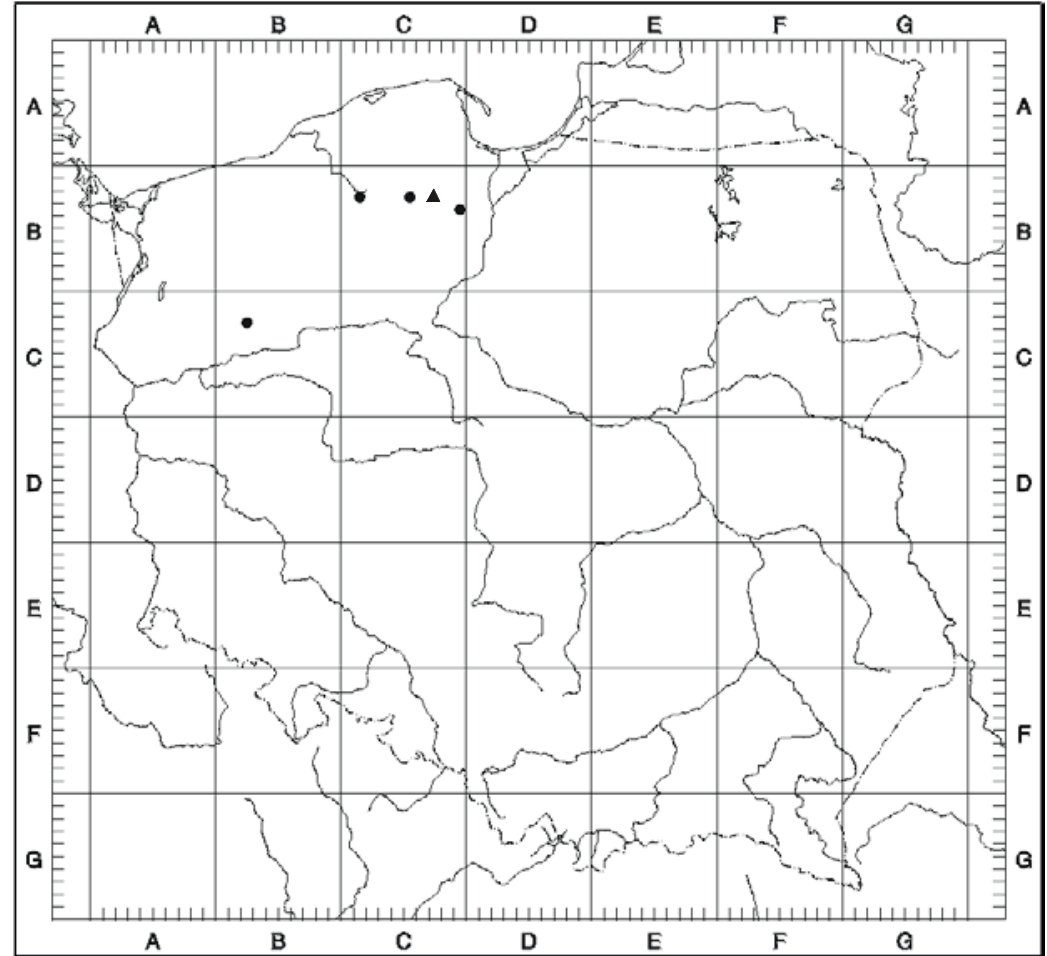

for identification (Fassett 1940). Characters of two different (parental) Potamogeton species should be noticed on a given specimen if it is to be regarded as a hybrid. These characters can be modified by influence of the genes from one parental taxon, which, in turn, could give a new character (often median between the parental ones). If a studied specimen does not possess the characters of two different taxa, it must be the effect of (sometimes extreme) variation.

Potamogeton $\times$ salicifolius Wolfg. from the Gatno lake resembles $P$. perfoliatus - one of its parent - in habit, but has distinctly different leaf base and stipules (Table 1, Fig. 2, 3). The habits of parental species (P. perfoliatus and $P$. lucens) are showed in „Atlas flory polskiej i ziem ościennych" (Mądalski 1977). This hybrid is extremely variable (Preston 1995). In some cases, when $P . \times$ salicifolius Wolfg. has slightly amplexicaul to semi-amplexicaul leaf base the differentiation between $P . \times$ salicifolius and $P . \times$ nitens is impossible if based on comparative morphology solely. The described specimens of $P . \times$ salicifolius Wolfg. have a cuneate leaf base thus such misidentification is excluded. not seen.
Fig. 1. Distribution map of Potamogeton $\times$ salicifolius Wolfg. in Poland using the ATPOL grid square system; s - the new locality.

\section{DESCRIPTION}

Stem up to $0.4 \mathrm{~m}$, terete, unbranched; nodal glands absent. Submerged leaves with the lamina 38-48-(52) mm long, 0.7-12 (-15) wide, translucent, yelowish green, narrowly oblong, gradually narrowed to a sessile base, apiculate and often slightly mucronate at the apex, denticulate and undulate at the margin; midrib prominent, bordered on each side by a narrow band of lacunae, the lateral veins 3 (4) on each side, 1 more prominent than the rest because bordered by a narrow band of lacunae, the secondary veins frequent, ascending, very few transverse towards the margin. Floating leaves absent. Stipules 10-14 (-16) mm, open, translucent hyaline, rounded at the apex, veins inconspicuous when dry, 2 slightly more prominent than the others but not forming distinct ribs. Turions and inflorescences

The specimens of $P . \times$ salicifolius Wolfg. from the Gatno lake are generally smaller than observed before by some authors (Preston 1995; Wiegleb, Kaplan 1998; ZalewskaGałosz 2002). Such width and length of leaves and length of stipules for this taxon have not been noticed before.

TABLE 1. Comparison of important characters of: $P$. lucens, $P$. perfoliatus and $P . \times$ salicifolius from the Gatno lake.

\begin{tabular}{llll}
\hline Character & P.perfoliatus & P. $\times$ salicifolius & $P$. lucens \\
\hline Leaf base & Amplexicaul, sessile & Gradually tapering (cuneate), sessile & $\begin{array}{c}\text { Abruptly or sometimes gradually tapering, on short } \\
\text { petiole }\end{array}$ \\
\hline $\begin{array}{l}\text { Leaf apex } \\
\text { Stipule }\end{array}$ & Rounded to obtuse, often slightly hooded & Apiculate and slightly mucronate & Mucronate \\
\hline
\end{tabular}




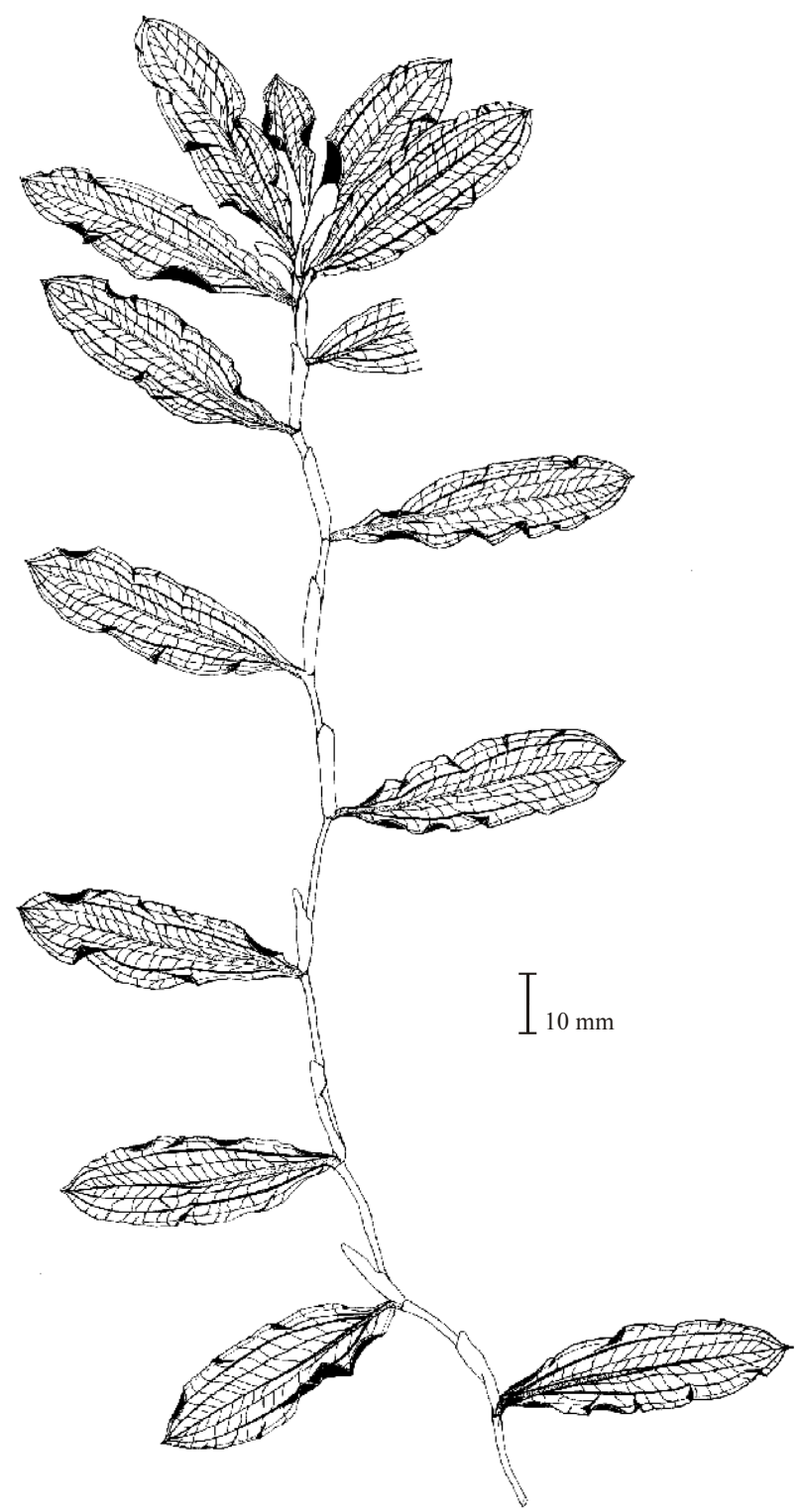

Fig. 2. The habit of $P . \times$ salicifolius Wolfg. from the Gatno lake. Based on herbarium sheet no. 0204443 (KRA).

\section{LOCALITY}

In July 2002 Potamogeton $\times$ salicifolius Wolfg. grew in the north-western part of the Gatno lake, 8 kilometres away from Kościerzyna, in the Kaszuby Lakeland, North-Western part of Poland, CB27 grid square system, according to ATPOL (Zając 1978). P. $\times$ salicifolius Wolfg. thrived on sandy bottom, in $0.4 \mathrm{~m}$ deep, mesotrophic water together with one of its parents $-P$. perfoliatus, which was very abundant in this lake. The other parental taxon $P$. lucens was absent in the lake. The population was small, consisting of five vertical, unbranched shoots, growing close to each other (distance up to $1 \mathrm{~m}$ between shoots). Shoots were vegetative only and probably arose from the same rhizome. The shoots showed very little morphological variation, which could confirm its genetic identity. Monitoring of this population in the next seasons is needed. Two herbarium sheets of $P . \times$ salicifolius Wolfg. from this locality were collected and deposited in KRA (no. 0204443, 0204445).
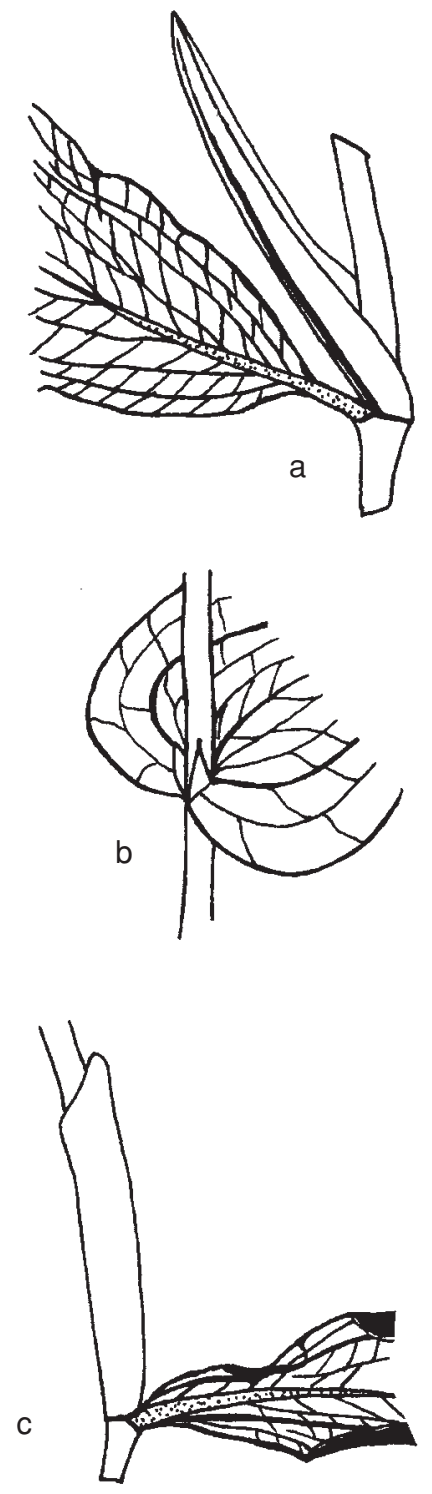

Fig. 3. Schematic illustration of the leaf base: a) P. lucens; b) P. perfoliatus; c) P. $\times$ salicifolius from the Gatno lake.

\section{CONCLUSION}

Potamogeton hybrids are still insufficiently recognised not only in Poland, but also all over the world. Capacity of hybrids to persist and spread vegetatively makes them morphologically and taxonomically important. Monitoring of hybrid localities in the future can provide new facts on their biology, habitat, variability and distribution.

\section{LITERATURE CITED}

FANT J.B., PRESTON C.D., BARRETT J.A. 2001. Isozyme evidence for the origin of Potamogeton $\times$ sudermanicus as a hybrid between $P$. acutifolius and $P$. berchtoldii. Aquatatic Bot. 71: 199-208.

FASSETT N.C. 1940. A manual of aquatic plants. McGraw-Hill Book Co., New York, ss. 382.

HOLLINGSWORTH P.M., GORNALL R.J., PRESTON C.D. 1995a. Genetic variation in British populations of Potamogeton coloratus (Potamogetonaceae). Pl. Syst. Evol. 197: 71-85. 
HOLLINGSWORTH P.M., GORNALL R.J., PRESTON C.D. 1995b. Isozyme evidence for hybridisation between Potamogeton natans and $P$. nodosus (Potamogetonaceae) in Britain. Bot. J. Linn. Soc. 117: 59-69.

KAPLAN Z. 2002. Phenotypic plasticity in Potamogeton (Potamogetonaceae). Folia Geobot. 37: 141-170.

LILIENFELDÓWNA F. 1919. Najadaceae, Jezierzowate. [In:] Flora Polska. Rośliny naczyniowe Polski i Ziem Ościennych. Raciborski M., Szafer W. (eds), Tom I. Paprotniki, Iglaste i Jednoliścienne, Akademia Umiejętności, Kraków, pp. 67-87 (in Polish).

MĄDALSKI J. (ed.). 1977. Atlas flory polskiej i ziem ościennych. Florae Polonicae terrarumque adiacentium iconographia. T 2 (1). PWN, Warszawa-Wrocław-Kraków (in Polish and Latin).

MIREK Z., PIĘKOŚ-MIRKOWA H., ZAJĄC A., ZAJĄC M. 1995. Vascular plants of Poland. A checklist. Polish Bot. Stud. Guideb. Ser. 15: 1-308.

PRESTON C.D. 1995. Pondweeds of Great Britain and Ireland. Botanical Society of the British Isles, London, B.S.B.I., Handbook Nr. 8, pp. 352.
SZAFER W., KULCZYŃSKI S., PAWŁOWSKI B. 1953. Rośliny Polskie. Opisy i klucze do oznaczania wszystkich gatunków roślin naczyniowych rosnących w Polsce bądź dziko, bądź zdziczałych lub częściej hodowanych. xxviii + ss.1020. PWN, Warszawa (in Polish).

WIEGLEB G. 1988. Notes on pondweeds - outlines for a monographical treatment of the genus Potamogeton L. Feddes Repert. $99(7,8) 249-266$.

WIEGLEB G., KAPLAN Z. 1998. An Account of the Species of Potamogeton L. (Potamogetonaceae). Folia Geobot. 33: 241$-316$.

ZAJAC A. 1978. Atlas of distribution of vascular plants in Poland (ATPOL). Taxon $27(5,6)$ : 481-484.

ZAJĄC A., ZAJĄC M. (eds). 2001. Distribution atlas of vascular plants in Poland. pp. 425-426. Edited by Laboratory of Computer Chorology, Institute of Botany, Jagiellonian University, Cracow.

ZALEWSKA-GALOSZ J. 2002. Occurrence and distribution of Potamogeton hybrids (Potamogetonaceae) in Poland. Feddes Repert. 113 (5, 6): 380-393.

\section{UWAGI O MIESZAŃCACH POTAMOGETON \\ NA PODSTAWIE CECH $P . \times$ SALICIFOLIUS WOLFG. Z NOWEGO STANOWISKA W POLSCE}

\section{STRESZCZENIE}

Informacje na temat mieszańców Potamogeton, ich identyfikacji, taksonomii, ekologii i rozmieszczeniu są nadal niewystarczające. Na podstawie cech $P . \times$ salicifolius z jeziora Gatno - nowego stanowiska w Polsce przedstawiony został sposób identyfikacji mieszańców Potamogeton. Zamieszczono opis morfologii $P$. $\times$ salicifolius z jeziora Gatno. Analiza jego ilościowych cech morfologicznych dostarczyła nowych informacji na temat zmienności tego mieszańca. W pracy zamieszczono także mapę rozmieszczenia $P . \times$ salicifolius $\mathrm{w}$ Polsce, oryginalną rycinę okazów z jeziora Gatno oraz tabelę z zestawieniem cech $P$. $\times$ salicifolius i gatunków rodzicielskich.

SŁOWA KLUCZOWE: mieszańce Potamogeton, zmienność, rozmieszczenie, Potamogeton $\times$ salicifolius Wolfg. 